\title{
THE CONTROL OF SHAPE: ORIGINS OF PARAMETRIC DESIGN IN ARCHITECTURE IN XENAKIS, GEHRY AND GRIMSHAW
}

\author{
Rodrigo GARCIA ALVARADO, Jaime JOFRE MUÑOZ
}

Received: 29.06.2011; Final Text: 21.03.2012

Keywords: parametric design; contemporary architecture; Xenakis; Gehry; Grimshaw.
Several contemporary architectural works are arguing use of parametric design technologies, without clearly identifying their essential conditions. This article reviews meanings of this term and its first literary uses in referring to architectural design, as well as initial works applying these techniques, with the purpose of clarifying its original sense and applications, to support a consistent development. The word has different meanings ranging from social to mathematical connotations, mostly related to a measurable variation. Meanwhile, the documents about architectural works consider the concept of parametric design from the stand point of management of building information to specific geometric operations. The works reviewed as early examples of parametric procedures in building design are the Philips Pavilion by Le Corbusier and Xenakis, the Barcelona Fish by Frank Gehry and the Extension of Waterloo Station by Nicholas Grimshaw. It comments on their general process of production, functional and construction issues involved in the design of these three cases. Geometrical and computer procedures are described in relation to shape definition, structural solution and design expression of each building. Based on the texts and cases reviewed, the article suggests a strict conception of parametric design in architecture, linked to variable curves, as well as a constructive and cultural sense.

\section{INTRODUCTION}

Recently, the use of the term "parametric design" has been widely expanded in the architectural work, mainly associated to the use of advanced digital technologies in complex projects (Meredith el al., 2008; Woodbury, 2010). However, this concept and its applications in architecture have not been properly clarified. The documents and programs devoted to parametric systems scarcely indicate definitions, basic characteristics and/or general uses in building design. They usually mention specific geometrical operations and/or constructive 
developments. In order to clarify its original sense and contribute to a consistent professional application and development, this article reviews the meanings of the term and its use in documents referring to architectural design, as well as early works applying parametric techniques in the generation of the building form; looking for the identification of its conditions and its participation in the design process.

First, the term "parametric design" associates the general action of the design to the adoption of "parameters". According official thesaurus, the word "parameter" refers to data that affect a situation (RAE, 2010), but all building projects are defined by external conditions, then that definition doesn't clarify well its particular condition in architectural design.

There is also a mathematical meaning of parameters which refers to a range of values. This concept was introduced by Joseph-Louis Lagrange in 1774 to identify some differential equations which uses additional variables (Nápoles and Negrón, 2002) and it was later on implemented in analytical geometry for complex curves. In statistics the term is used to the distribution of data and it characterizes a branch of that discipline; "parametric statistics". Frequently, this word is associated to a modifiable magnitude, and sometimes it refers to the limits of one action, whether numeric or qualitative (such as habits or normal behavior). That is to say, its meaning is placed between a social and a mathematical sense, linked primarily to a measurable variation.

The use of this term in computational design came up in the decade of the seventies, with the emergence of methods to describe curves through parametric equations, from the seminal work of Steve Coons (1967), who proposed the definition of skewed surfaces by the subdivision in compound patches of four edge curves defined by similar equations for easier operation. This strategy complemented the initial computer representation methods that used simpler mathematical descriptions, but those were excessively long to manipulate complex shapes. This principle came up to define curved traces and volumes (like splines) which are implemented nowadays in most design software, though without distinguishing them in particular and providing a limited control (Woodbury, 2010). Also, it may be considered that all digital drafting operations use parameters in the sense that they use numeric data that can be modified, controlled and/ or saved, though the conditions are diverse among programs.

The possibilities of parametric features of digital design in architecture were first stated by Gross (1990), who exposed that they were useful to elaborate typical variable forms. In his PhD thesis (Gross, 1986), he suggested modeling building with formal and economic restrictions, He mainly discussed alignments and distancing of regular figures. A little later, Schnoedt (1992) conducted a broad discussion towards the architectural implications of parametric design, based on the flexibility of available forms from the first design software. He related this capability to the industrialization and the possibility of prefabricating components, discussing the cognitive aspects and operational in the design process. Also, he connected it to the prototypes or cultural archetypes of traditional building, which challenge the originality of architectural creations.

An explicit recognition of parametric procedures in the generation of architectural design was carried out afterwards by Serrano (1993) when he presented works to complete Gaudi's Temple of the Holy Family with computer models based on intersection ruled surfaces. But it was 
not until a decade later that the architectural capabilities of parametric design were extensively reviewed in a master's degree thesis in the MIT (Gane, 2004). This suggested a cultural change from these possibilities of the forms; recognizing parameters as the modeling variable of structural components. Also, Dennis Shelden, head of the informatics team of Frank Gehry, in this PhD thesis presented in the MIT (Shelden, 2002), exposed the digital management of his buildings' development, with applications of parametric design.

These documents reflect certain delay in the discipline to recognize those properties of computational design; though with an early discussion of potential implications; considering the concept of parametric design from the stand point of management of building information to specific form features. Recently, parametric design in architecture has been put forth as a general style (Schumacher, 2008) or as an attitude of major creative potential through particular procedures (Woodbury, 2010). That is to say, as geometric properties or professional capabilities. Therefore, it is also relevant to review some of the first works in which the use of parametric design is adduced, since they may show essential characteristics of this technique and its professional application.

A use of the word "parametric" is found prematurely in some unexecuted works by the Italian architect Luigi Moretti carried out in 1960 for a stadium, (Moretti, 2010). But according to Prousalidou (2006, 25), the first building brought to life in which the use of parametric systems is said to have been used are the Philips Pavilion designed by Le Corbusier and Iannis Xenakis for the Brussels World's Fair in 1958 (though without computational methods). Also, according to Shelden $(2002,27)$, the fish-shaped roofing installed by Frank Gehry in the Olympic Village in Barcelona in 1992, and according to Szalapaj $(2001,131)$ and Gane (2004, 45), the Waterloo Terminal by Nicholas Grimshaw concluded in 1993. For all these cases, parametric techniques have been detected, and in the last two buildings, tri-dimensional digital modeling was used. Those examples show explicit use of variable curves for the constructive solution and cultural expression of buildings that suggest specific properties of parametric design in architecture.

\section{THE PHILIPS PAVILION, Brussels, 1958}

Brussels World Fair took place from April 17th to October 19th, 1958, with the participation of 43 countries that held expositions within an area of 200 ha. The Dutch company Philips, entrusted Le Corbusier with the design of a pavilion that would show the technological improvements in light and sound. Le Corbusier formed a broad team of co-operators, including the engineer and musician Iannis Xenakis, to conceive the pavilion as a container for the projection of a great audiovisual spectacle (Makis, 2001; Kanach, 2009).

The "Electronic Poem", elaborated that same year by Le Corbusier as a realization of the total integration of all the arts, was conceived as a multi-sensorial experience for the visitors of the Philips Pavilion. This work included electronic music created by Varèse and Xenakis, and the projection of images in the interior walls of the pavilion that recounted aspects of human history (Moreno, 2008). According to Xenakis' drawings, who worked from 1948 as structural engineer in Le Corbusier's office, the sound would follow the continuous visit of the pavilion, with higher 


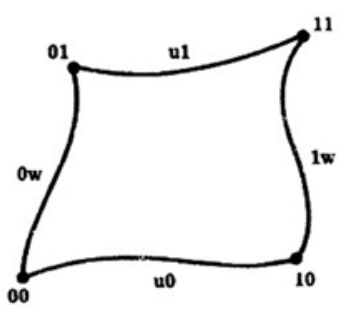

Figure 1. Curved Surface Description (Coons, 1976, 8).
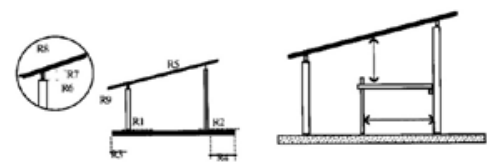

Figure 2. Constructive Parametric Description (Gross, 1990, 128).

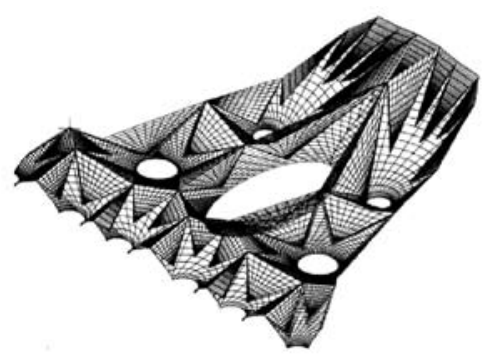

Figure 3. Representation of building's parts of Gaudi's Temple of the Holy Family (Serrano et al., 1993, 9).

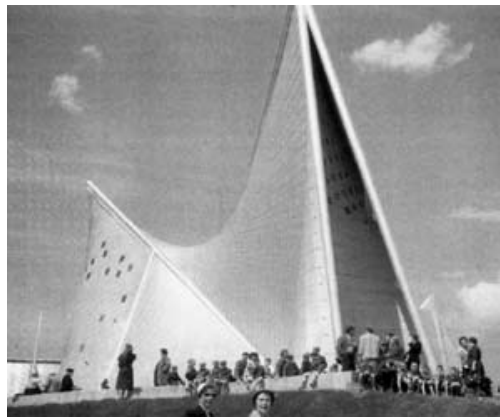

Figure 4. Philips Pavilion (Kanach, 2009, 151). and lower intensity and diverse positions so that when heard, it would narrow or extend the oral space of the audience. Based on his experiments in the composition "Metastaseis" created between 1953 and 1954, Xenakis was elaborating a continuous variation within music work, through intermediate tones (called "glissandos"). Thus the architectural intention was to express cultural achievements through the continuity of the visitors' experience.

Following a curve-shape scheme outlined by Le Corbusier, with entrance and exit on both sides, Xenakis proposes the use of eight developable ruled surfaces produced by the movement in the space of one straight line as geometric generator, to cover the surface of $500 \mathrm{~m} 2$ required through a constructive system comprising concrete prefabricated panels to get curved walls with straight pieces. In the floor plan the three main connected spaces can be noted, which make up the tour: the entrance and the technical room, the great room for the audience and the exit.

The drawing called Croquis $\mathrm{N}^{\circ} 11$ expresses the process carried out by Xenakis for the geometric composition of the shape of the pavilion (Figure 6). According to the description given by the same Xenakis (Kanach S. 2009), this drawing reproduces four figures originated in the cone. The conical volume " $\mathrm{E}$ ", the joint " $\mathrm{L}$ " and the surface generated in the relation of two of them (A / D); as well as two hyperbolic paraboloids (G / K) and lastly, two empty triangles that configure the accesses to the pavilion. Hyperbolic paraboloid surfaces were considered in order to simplify the structural estimation and construction, and at the same time, giving a slender configuration and brightness to the form. In the definitive version (Figure 7), conical-shape forms A, D and E were replaced by hyperbolic paraboloids shapes to which other four have been added, named B, N, $\mathrm{C}$ and F. In order to meet the second point, it was necessary to increase the difference in height between the vertexes, leaving the first of them in 21 metres. This process implied relating straight intersections edges and the oscillating curve-surfaces display with its projection in the floor plan, appealing to traces that demanded a parametric formula of development through hyperbolic paraboloids (Prousalidou, 2006). So, the projection of curves in intersections planes with vertex points and straight traces gave a parametric control of shape for the constructive development. Using the radius of curves for generation of profiles connected between them, and loft in different height diagonals to create variable surfaces intersected (Kanach, 2009, 176). This geometrical depiction defined the design of structural walls with mutual support and slight curved configuration,
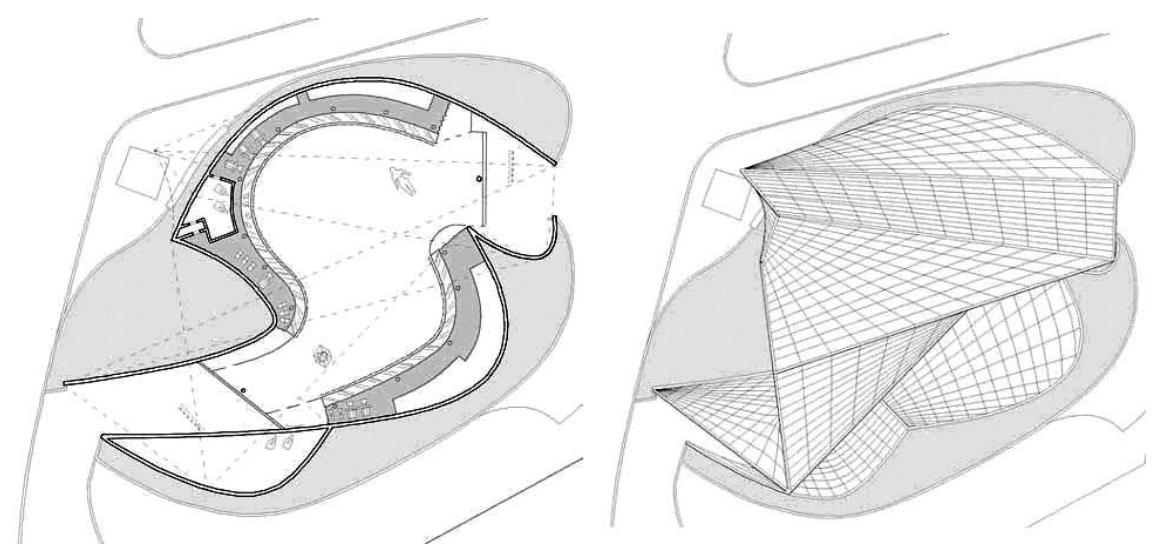


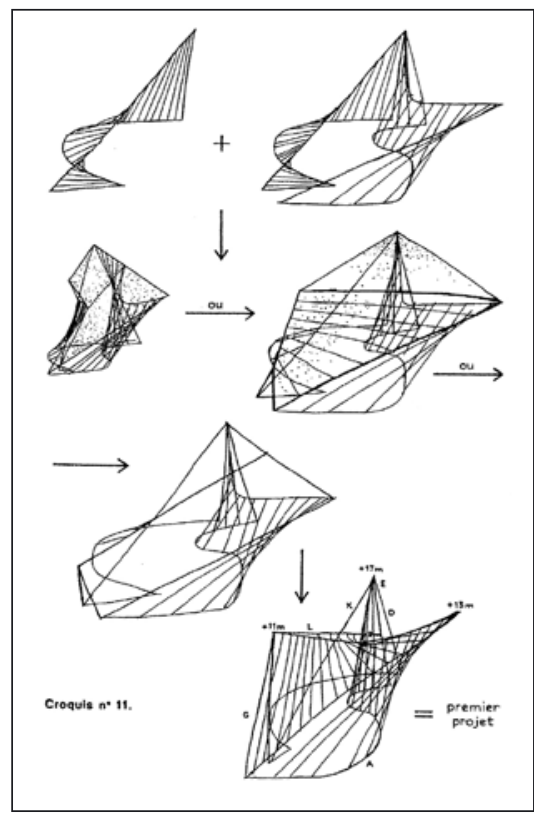

Figure 6. Croquis $\mathrm{N}^{\circ} 11$. I. Xenakis: First version of the structural concept (Makis, 2001, 158).

Figure 7. $2^{\circ}$ Project. I. Xenakis: Second version of the structural concept (Makis, 2001, 220).

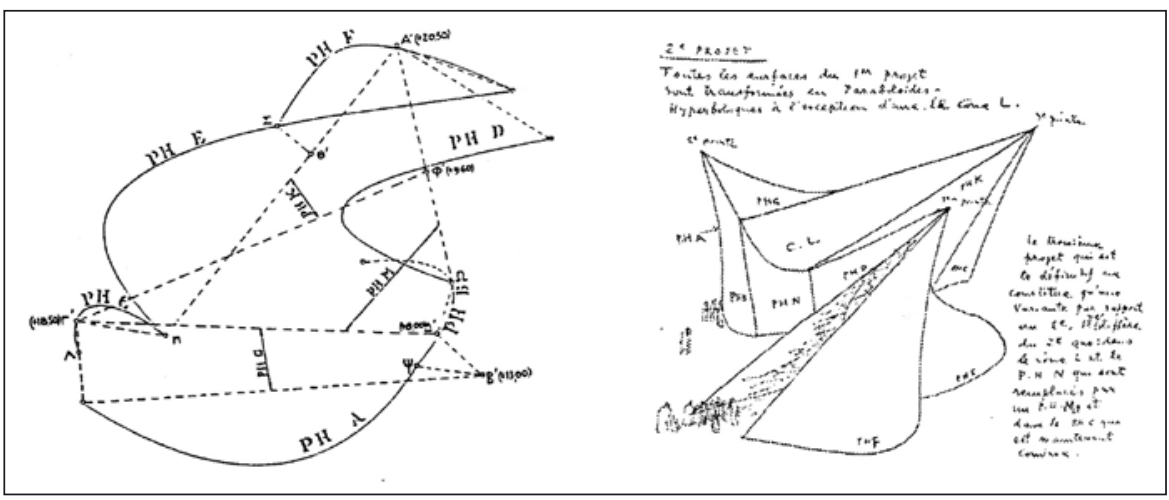

to get spatial continuity and innovative expression. The pavilion was completed with a lateral cellar, basements and several fenestrations.

\section{THE FISH, Barcelona, 1992}

The group of buildings executed by Frank Gehry in the city of Barcelona from 1989 to 1992, were part of the plan elaborated for the Olympic Games, with the purpose of recovering the coast line (Dal Co et al, 1998). It was an industrial area, segregated of the city by the railroad lines that had turned the nearby beaches into waste deposits. Therefore, it was considered to integrate the urban layout to the coastline through a system of public spaces and equipment. Including the Hotel Arts and adjacent commercial areas designed by Frank Gehry and associates. The project considered a surface of $14,000 \mathrm{~m} 2$ organized around a central patio between the hotel and the beach, forming multiple routes with restaurants and bars. The roofing of the patio considered a $49 \mathrm{~m}$ long and $30,5 \mathrm{~m}$ tall metallic structure that acts as a protection from the sun. Two basic parts are noticed: a supporting white steel reticular structure and a metal cover that evokes a fish surface.

In Frank Gehry's work, the fish is a recurrent figure since its beginnings, used in the form of lamps for the unbuilt project of Smith House and the Collaboration Exposition in 1981. He worked with a model and scales that revealed him the symbolic potential of this figure (Gehry, 1988). Also that year, the project for the reinsertion of houses in Michigan included a fish-shaped hotel. However, he was only able to realize it in light sources for the Venice restaurant and in other lamp proposals for the Formica's Campaign in 1982. Two years after he exhibited in Nueva York the design of fish-shaped cells. Also, in the proposal for the Fish Dance Restaurant in Kobe, Japan in 1986, he incorporated it as sculptures in the facade of the building.

For the design of this roof in Barcelona, the first fish-shaped set up that he uses at architectural scale, Gehry's study used the software Catia, by Dassault Systemes, previously applied to the design of cars and aircrafts. This computer program enabled to work on a digital model in three dimensions (Figure 9) and to be connected with the production or the digitalization of material models. It is worth mentioning that the physical models occupy an important place in Gehry's design process to encourage designers to experiment and get away from the outlines of the orthogonal geometry. Therefore, computer programs combine in a coherent digital representation the demands of the constructive system and 
Figure 8. Fish Structure in the Olympic Village in Barcelona (Marco Cardenas).

Figure 9. Digital Model of the Structure (Dal Co et al, 1998, 431). the experimentation with non-conventional shapes. Gehry states that the relationship between the design solution and the cost that its elaboration demands constitutes one of the most important variables in the decisions of the shape. Maintaining the equilibrium between the architectonic characteristics of volume, plastic expression, constructive system and materiality, is a task conditioned by the budget.

James Glymph, responsible for the digital design, first made contact with William J. Mitchell, professor in Harvard who, together with the student Evan Smythe, developed the basic design model in the software Alias (Shelden, 2002). However, when using it, it represented a curve-shape
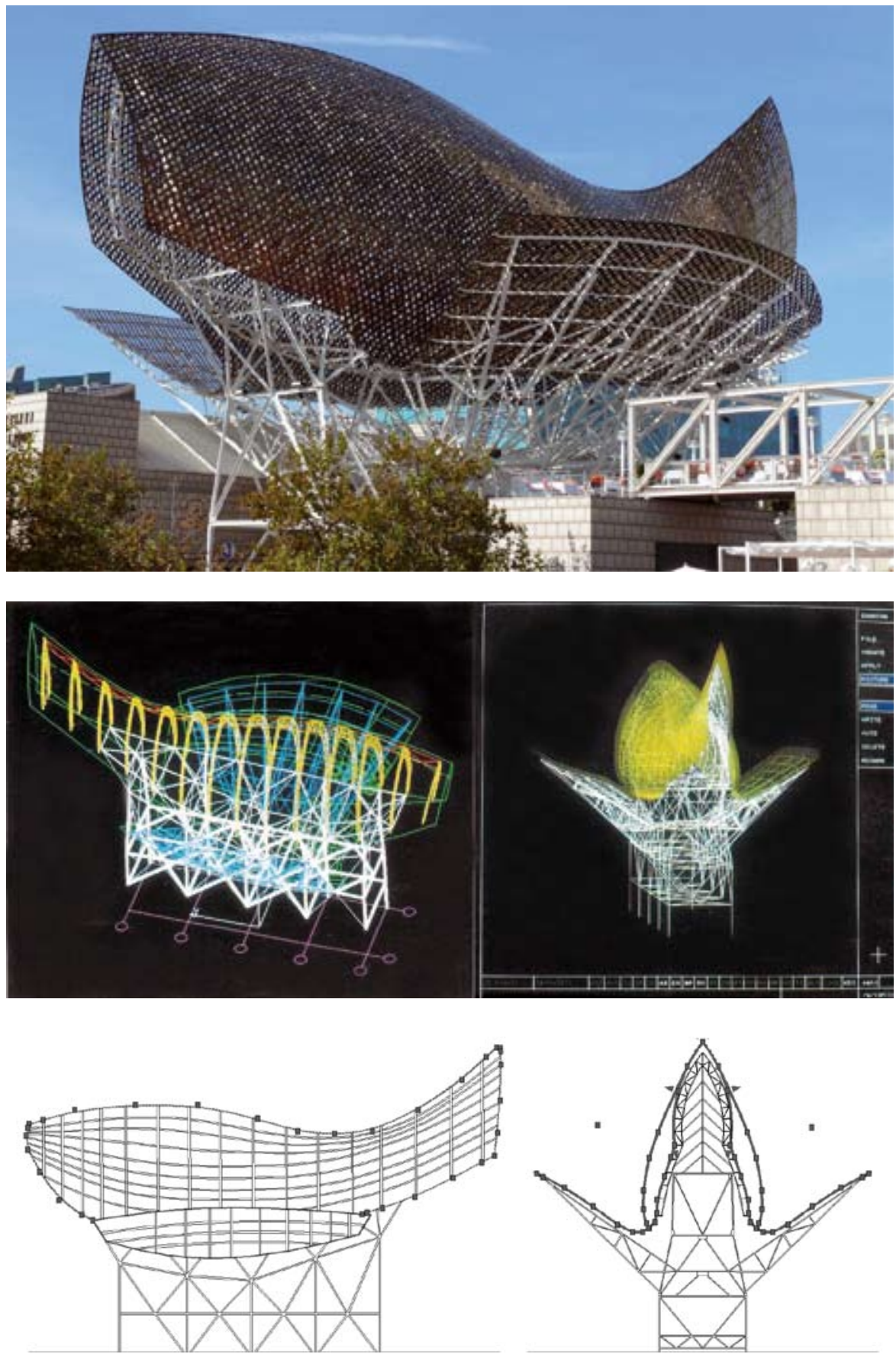

Figure 10. Parametric curves in the structure of Gehry's Fish (by authors). 
surface through triangular faces, with vaulted armor made of structural steel ribs. But the intersection between the curve plan and the truss caused a set of segmented polylines that made it difficult to establish correctly the constituent elements. Therefore, the software Catia was used later, in order to develop parametrically the curve of the surface and thus enabling to define the steel profiles of the mesh required to build it. Through a hermite curve for interpolation of structural ribs and define the surface's pieces by tessellation, like a grid of polygons for unfolding them to production (Schodek et al, 2005). Using the length and high of each section profile like main geometric parameters and curve's control points as variable, as well as modular relationship in the three dimensional model by transverse segments. Even though the shape of the roof is a volumetric simplification of the figure of a fish, it is evident that the previous interests of the architect and the symbolic circumstances of the location promoted this intention to express its coastal situation. The structure is visible at distance within the beach landscape, so its texture and silhouette was greatly relevant. This led to conceive a structure that provided a profile evoking a fish from different points from the distance, supported by a mesh of straight pieces.

His former studies might have revealed to him the expressive capacity of the tapering figure to suggest a fish, compressed symmetrically in the longitudinal vertical section, but with an expansion in one end. In this way he avoided form details or material representations generating a subtle symbolism at a great visual scope. However, this implies double-curved surfaces, and especially in the back, with a change of direction. This last volume alteration was crucial to avoid the simple dynamic connotation that all the tapering figure has (like a boat or cover), applying at the end a concave return resembling a fish, due to the propellant ending that the species have. So he installed this profile horizontally to make it easier to support it and provide a shady cover, excluding in particular the finish of the taps, which he left open. He simplified the fins on each side extending them from the volumetric stretch, to cover a larger horizontal surface and leaving an extended pointed arch as the main section, assuming that the vision from distance would concentrate in the profile and changing shin of the volume.

Gehry had determined these variable double-curved surfaces in different materials and textures, but in smaller elements, by using the set up of small intertwined pieces forming the support and cover at the same time. In this case he used flexible strips fitted in the pipe ribs of the structure, and he required adjust these two arrangements by the digital model in CATIA. He understood then that he had to separate the supporting structure from the representative surface, as it has happened often in the history of architecture, for example, with the renaissance domes and more recently in the Sydney Opera House; laying out a support inferior scheme and a sustained variable cover. But this strategy requires a precise trace of different curves to combine them with regular distances of the support and accurate fabrication of pieces. This geometric interrelation between the structure's modulation and the complex curvature surface led to the challenge of using digital parametric geometries that generated a new step in the professional work, allowing construction of curved profiles for symbolic potential of buildings. 


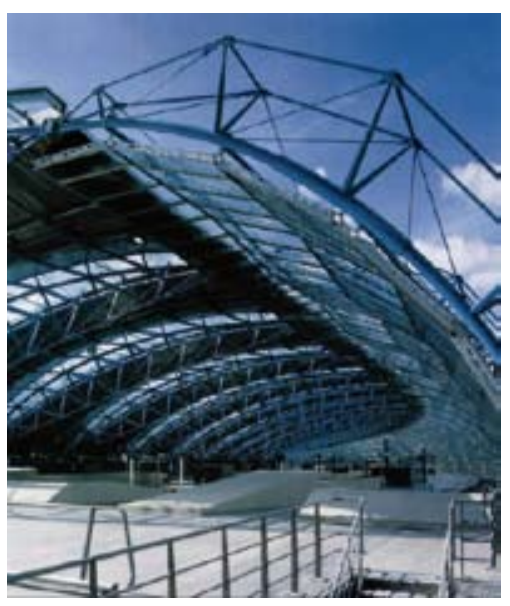

Figure 11. Front view of Waterloo Terminal (Moore, 1995, 1).

Figure 12. Section and Floor Plan of Waterloo Station (by authors).

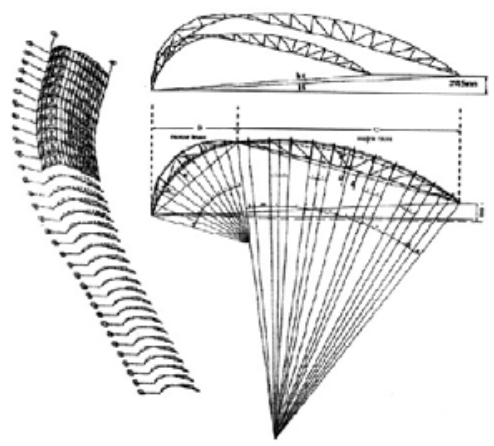

Figure 13. Parametric development of the roof trusses (Szalapaj, 2001, 138)
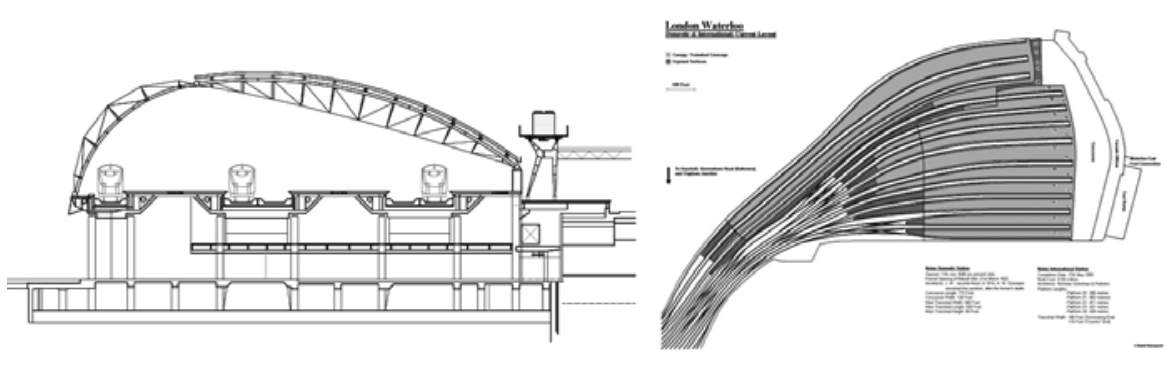

\section{THE WATERLOO INTERNATIONAL STATION, London, 1993}

Waterloo Station, located in the heart of London, is a major international train terminal, moving more than 15 million passengers a year in 60,000 $\mathrm{m} 2$. In 1993 it had to be extended to become the main terminal for the Eurostar train which enabled a fast connection with Paris and Brussels. The extension and complete renewal of the terminal was led by of Nichols Grimshaw's architectural office and several engineering teams.

The purpose of the project was to complete the station incorporating an expression of smooth flow, to evoke the industrial era, but also the new way of transportation (Grimshaw, 2010; McGuckin et al, 1994). The area available for the extension had the necessary width to accommodate only five additional railways, limited by the electrical network on one side and the roads on the other, in a winding area and that narrowed toward the interior. The extension had to be added to the existing station. In doing so, it provided uniqueness by showing new traveling possibilities, especially though its $400 \mathrm{~m}$-long roof. The cover was a particular technical challenge due to its asymmetric shape in the acute profile of the area and due to the fact that it had to rise up progressively to fit the height of the trains. The eastern side is clad entirely in glass. Towards the entrance it offers and impressive view of the River Thames and Westminster and on the other side, it becomes a panoramic showcase for the long Eurostar trains.

Structurally the roof structure consists of pairs of three-pinned bow strings arches; the central point displaced towards one of the sides enables the bow shape in the higher area from West to East. This complex structure covers an area that goes from $50 \mathrm{~m}$ wide in the entrance to $35 \mathrm{~m}$ towards the end of the platform. The roof is flexible, with a limited range of glass tiles of different sizes overlapped that can shrink and expand according to the different spins of the roof.

The structure is formed by two dissimilar curved trusses, a larger one stretched in the inner side and a smaller one and curved, stretched in the top end. Also, the beams make up 35 modules that vary in dimensions. The design was modeled by Lars Hesselgren in the software I_EMS, and afterwards it was re-modeled by Robert Aish with Microstation Generative Components. The trusses were defined by a program that modifies the inner measurements of each module according to the proportional scale factor to the length by means of Pythagorean relation keeping the centres 
for the radial layout of the smaller pieces. By propagation of the formula, changing the wide of the structure (the chords of curves) and maintaining the central axis like a curved profile. Such produces a continuos surface with a variable section, with proportional heights of the beams according the lights of support. The mathematical description enabled the generation of each design by means of altering the numerical parameters (Szalapaj, 2001).

The covering is the main architectural challenge of the Terminal and its magnitude provides the perception that almost the whole building is enclosed. Shifting the attention from the vault work composing the old terminal (refurbished as warehouses and food courts) to a new fluid space that covers a parking lot next to the underground and two levels of viaducts above which stand two floors for passengers (arrivals and departures). The design shows the variation of structure that resembles mobility and technology of new transportation media.

\section{CONCLUSIONS}

Parametric design has been spread out in architecture without complete clarification of its particular features. This text at the beginning reviews the connotations of the term, disclosing its mathematical and social meaning; as well as the first documents that mention this technique in computer graphic and architectural design, observing a geometric and constructive sense. Then three works are described, in which initially these techniques were applied, manually in the Philips Pavilion by Le Corbusier and Xenakis in 1958, and with incipient computer systems in the Fish of the Olympic Village of Barcelona, by Frank Gehry in 1992 and the extension of the Waterloo Station in London by Nicholas Grimshaw in 1993.

These projects show a detailed handling of curve-shape forms in significant elements for construction, using relatively complex geometrically procedures, in the last cases digitally, which stand out because they vary the profile in an irregular manner, in the encircling walls of the Pavilion and the covering of the Fish and the Waterloo Terminal. This variable profile is the essential property of the parametric equation curves, which suggests a formal definition of the parametric design; distant from external references, restrictions or regular alterations, which are the general interpretations of the concept parameter gathered from documents connected to constructive modelling. In this sense, a strict parametric design condition is observed in these architectural works, associated to variable curve-shapes. Using different procedures and tools, but all related to trace irregular bend shapes, composed by diverse profiles and modular surfaces related. In order build a coherent three-dimensional geometry of complex volumes.

Besides, it is worth notice how the elements traced entail constructive definitions, and provide at the same time a determined space and cultural expression. Apparently the application of parametric design in architecture is placed in the dilemma between the conception and the execution of the architectural form. With an operational sense, but it is also related to symbolic connotations, as also demonstrate recent examples of parametric design in architecture (Hudson et al, 2011 and Miller, 2011). The need for a material representation of these complex shapes relates it to internal processes and external functions. The connotations involved do not come up so much for their tracing, but mainly for their variations. Thus, the 
parametric techniques that provide the geometric control of these irregular figures participate in specific actions, which generate overall attributes of the shape; its constructive resolution and its symbolic projection within a comprehensive architectural control. In this sense, the parametric technique plays an instrumental role, but also provides with an expressive potential.

The work of Xenakis and Le Corbusier in 1958 allows us to state that the absence of parametric design software was not an obstacle for the development of complex surfaces. In this case, the architectural idea of the indoor continuity and outdoor innovation, it is elaborated through conical shapes and hyperbolic paraboloids. The process of generating the form was slow and industrious, but this was not a reason for it to be vague or restrictive. In the case of the Gehry's Fish, in 1992, the software was a management and coordination tool between designers and the builders of the structure, but the conception of the figure was originated by the ideas of the author and the situation of the work. Also, the Waterloo International Terminal in 1993 shows signs that computer programs provide the capabilities to define the form, according to the professional skills and the general requirements of the building. Then, it is shown that the parametric design capabilities open possibilities to the architectural work in a formal, as well as in the constructive and cultural sense.

\section{BIBLIOGRAPHY}

La arquitectura de Frank Gehry (1988) Gustavo Gili, Barcelona.

COLOMINA, B. (2004) Una conversación con Frank O. Gehry. El proceso de diseño, El Croquis 117; 6-18.

COONS, S. (1967) Surfaces for Computer-Aided Design of Space Forms, MITTechnical Report, Cambridge.

BURRY, M., MURRAY, Z. (1997) Architectural Design Based on Parametric Variation and Associative Geometry, Challenges of the Future 15th eCAADe Conference Proceedings, Vienna.

DAL CO, F., FORSTER, K. W., SOUTTER ARNOLD. H. (1998), Frank O. Gehry: Tutte le opera, Electa, Elemond Ed, Milano.

GANE, V. (2004) Parametric Design: A Paradigm Shift?, Master's Thesis, MIT, Cambridge.

GRIMSHAW, N. (2010) International Terminal Waterloo, www.grimshawarchitects.com/print/projectdata.php.

GROSS, M. (1986) Design as exploring constraints, Ph.D. Thesis, MIT, Cambridge.

GROSS, M. (1989) Relational Modeling: A Basis for Computer-Assisted Design, The Electronic Design Studio: Architectural Knowledge and Media in the Computer Era, CAAD Futures '89 Conference Proceedings, Cambridge; 123-36.

HUDSON R., SHEPERD P., HINES D (2011) Aviva Stadium: A case study in integrated parametric design, International Journal of Architectural Computing (9:2) 187-204.

KANACH S. (2009) "Música de la arquitectura. Iannis Xenakis", Akal, Madrid.

MAKIS, S. (2001) Présences de Iannis Xenakis, Centre de Documentation de la musique contemporaine (CDMC), Paris. 
MEREDITH et al (2008) From Control to Design; Parametric/Algorithm Architecture, Actar, Barcelona.

MILLER, N. (2011) The Hangzhou Tennis Center: A Case Study in Integrated Parametric Design, Parametricism (SPC) ACADIA Regional 2011, U. Nebraska-Lincoln.

MC GUCKIN, S.; STOWELL, G.; SOUTHCOST, G., MARTIN S.J.G. (1994); Project Profile, Waterloo International, British Cement Association, London; 17.

MOORE, R. (1995), Structure, Space and Skin: the work of Nicholas Grishaw \& Partners, Phaidon, London.

MORENO S. (2008) Arquitectura y Música en el siglo XX. Caja de Arquitectos, Barcelona.

MORRETTI, L. (2010) “Opere e progetti”, www.archittetoluigimorretti.

NAPOLES, J.; NEGRÓN, C, (2002) La historia de las ecuaciones diferenciales, Revista Electrónica de Didáctica de las Matemáticas (3:2) 33-57.

PROUSALIDOU, (2006) A parametric system of representation based on ruled surface, Master Thesis, UCL, London.

RAE (2010) “Diccionario", Real Academia Española, Madrid.

SCHNOEDT, H. (1991) Cultural Parametrics, Reality and Virtual Reality, ACADIA Conference Proceedings, Los Angeles; 223-34.

SCHODEK, D.; BECHTOLD M.; GRIGGS, K.; MARTIN K; STEINBERG M. (2005) Digital Design and Manufacturing, Wiley, New Jersey.

SCHUMACHER, P. (2008) “Parametricism Manifesto”, www. patrickschumacher.com.

SERRANO, J.G., COLL, J., MELERO, J.C., BURRY, M. (1993) The Need to Step Beyond Conventional Architectural Software, eCAADe Conference Proceedings Eindhoven.

SHELDEN, D. (2002) Digital Surface Representation and the Constructibility of Gehry's Architecture, PhD Thesis, MIT, Cambridge.

SZALAPAJ, P. (2001), Parametric Propagation of the Form, CAD Principles for Architectural Design, Architectural Press, Oxford; 131-40.

WOODBURY, R. (2010) Elements of Parametric Design. Routledge, New York. 
Alınd1: 29.06.2011; Son Metin: 21.03.2012 Anahtar Sözcükler: parametrik tasarım; çağdaş mimarlık; Xenakis; Gehry; Grimshaw.

\section{BİÇIMIN DENETIMII: XENAKIS, GEHRY VE GRIMSHAW MİMARLIĞINDA PARAMETRİK TASARIMIN KAYNAKLARI}

Günümüzde pek çok çağdaş mimari tasarım nesnesi, parametric tasarım teknoolisinden yararlandığını iddia etmekle birlikte, bunun temellerini oluşturan düşünceleri açmakta yetersiz kalıyor. Makale, bu terimin anlam(lar)ını gözden geçirirken, bu yaklaşımı ortaya koyan ilk ürünleri gündeme getirmeyi, ilk özgün ortaya çıkış ve uygulamalarını sunmayı, alanın sürekliliği ve gelişmesi açısından anlamlı buluyor. 'Parametrik' sözcügü sosyal ve matematiksel yan-anlamlar arasında gidip gelen, ölçülebilir çeşitlemeleri içeren farklı karşılıklara sahip. Öte yandan mimari ürünlerle ilgili belgeler, 'parametrik' tasarımı yapıyla ilgili olan bilgimizin özgül geometrik uygulamalar sırasındaki ele alınışıyla (işletim; management) ilişkilendiriyor. Bu yazıda, bina tasarımında 'parametrik' işlemlerin kullanıldığı erken örnekler olarak ele aldığımız

Le Corbusier ve Xenakis'in Brüksel Sergisi için tasarladıkları Philips Pavyonu; Frank Gehry'nin Barselona Balığ1; Nicholas Grimshaw'un Londra Waterloo İstasyonu Yeni Örtüsü, tasarlanma aşamalarında kurulan süreçler ile işlevsel ve inşai farklı yapılanmalar açısından ele alınıyor. Yapıların biçimsel tanımlanmaları, strüktürel çözümleri ve tasarımsal ifadeleri, geçirdikleri geometrik ve bilgi-işletim merkezli tasarım karar süreçleri ortaya konuyor. Örnek durumlar ve okumalar üzerinden makale, mimarlıkta 'parametrik' tasarımın somut olarak nasıl ele alınabileceğini, farklılaşan eğimli geometriler, yapısal oluşumlar ve kültürel anlamlar üzerinden tartışmayı hedefliyor.

RODRIGO GARCIA ALVARADO; BArch, MS, PhD.

Architect (Catholic University of Chile, 1989), Master's in Information Technologies (Polytechnic University of Madrid, 1994) and Ph.D. in Architectural Representation (Polytechnic University of Catalunya, 2005). Currently is Associate Professor and Head of PhD Programme in Architecture, at University of Bio-Bio, Concepcion, Chile.

JAIME JOFRE MUÑOZ; BArch, Ph.D.

Has BArch (University of Bio-Bio, 1987) and PhD in Architectural Design degrees (Polytechnic University of Catalunya, 2008), and works as practicing architect. Currently is Assistant Professor and Post-doctoral Researcher in University of Bio-Bio, Concepcion, Chile. 